\title{
Article
}

\section{Preparation of MOF(Fe) and its catalytic activity for oxygen reduction reaction in an alkaline electrolyte}

\author{
Guoqiang Song a , Zhiqing Wang a, Liang Wang c, Guoru Lic, Minjian Huang c, Fengxiang Yin b,c,* \\ a College of Pharmacy \& Life Science, Changzhou University, Changzhou 213164, Jiangsu, China \\ b State Key Laboratory of Organic-inorganic Composites, Beijing University of Chemical Technology, Beijing 100029, China \\ c Changzhou Institute of Advanced Materials, Beijing University of Chemical Technology, Changzhou 213164, Jiangsu, China
}

\section{A R T I C L E I N F O}

\section{Article history:}

Received 31 July 2013

Accepted 15 October 2013

Published 20 February 2014

\section{Keywords:}

Metal-organic frameworks

Hydrothermal process

Oxygen reduction reaction

Oxygen evolution reaction

Lithium-air battery

\begin{abstract}
A B S T R A C T
Effective bifunctional catalysts play a vital role in large-scale commercial applications of rechargeable lithium-air batteries. In this article, a metal-organic framework, MOF(Fe), was prepared by a hydrothermal process using ferric nitrate as the metal ion precursor and trimesic acid as an organic ligand. The structure of the $\operatorname{MOF}(\mathrm{Fe})$ was characterized by X-ray diffraction, $\mathrm{N}_{2}$ adsorption-desorption, Transmission electron microscopy, Fourier transform infrared spectroscopy and Thermo-gravimetric analysis. The activity for the oxygen reduction reaction (ORR) and the kinetic behavior of the ORR using the $\mathrm{MOF}(\mathrm{Fe})$ were investigated by cyclic voltammetry and rotating disk electrode voltammetry, respectively, using an alkaline electrolyte. The characterization results showed that the MOF(Fe) was highly crystalline with abundant micropores, large specific surface area and high thermal stability. The MOF(Fe) exhibited excellent catalytic activity for the ORR. The ORR mechanism varies with the applied potentials. The ORR occurs through a two-electron pathway at potentials in the range of -0.30 to $-0.50 \mathrm{~V}$, but shifts to four-electron pathway with the potentials in the range -0.50 to $-0.95 \mathrm{~V}$. In addition, the $\mathrm{MOF}(\mathrm{Fe})$ shows excellent catalytic activity for the oxygen evolution reaction (OER) in an alkaline electrolyte. This work opens a new route for the development of effective non-precious metal catalysts based on MOFs for the ORR and OER.
\end{abstract}

(c) 2014, Dalian Institute of Chemical Physics, Chinese Academy of Sciences. Published by Elsevier B.V. All rights reserved.

\section{Introduction}

The theoretical energy density of the lithium-air battery is about $11.1 \mathrm{kWh} / \mathrm{kg}$, which is equivalent to that of the gasoline-oxygen system [1-3] and is 10 times higher than that of the state-of-the-art lithium ion battery [2-4]. In addition, the lithium-air battery is light, non-toxic, pollution-free, and low cost. Therefore, lithium-air batteries have been regarded as very promising secondary batteries. However, the oxygen evolution reaction (OER) during the charging process and the oxygen reduction reaction (ORR) during discharge are sluggish, resulting in large overpotentials, which significantly lower the round-trip efficiency and cycle life of the battery. This limits the practical application of the unit as a secondary battery. In recent years, bifunctional catalysts [5] for the OER and the ORR have been proposed for applications in lithium-air batteries. The bifunctional catalysts accelerate the OER and also the ORR, reducing the charge/discharge overpotentials and thereby significantly enhancing the performance of the lithium-air battery. These findings pave the way for the commercialization of

\footnotetext{
* Corresponding author. Tel: +86-10-64412054; Fax: +86-10-64419619; E-mail: yinfx@mail.buct.edu.cn

This work was supported by the National Natural Science Foundation of China (21276018), the Beijing Outstanding Talents Project (2012D009016000003), the Natural Science Foundation of Jiangsu Province (BK2012596), and the Changzhou Science and Technology Program (Industrial Support) (CE20120034).
}

DOI: 10.1016/S1872-2067(12)60729-3 | http://www.sciencedirect.com/science/journal/18722067 | Chin. J. Catal., Vol. 35, No. 2, February 2014 
the rechargeable lithium-air battery.

At present, $\mathrm{IrO}_{2}$ is considered to the best catalyst for the OER. However, Ir is very rare and expensive, and even more expensive than Pt [6,7], and cannot meet the requirements of commercialization. Recently, some non-precious metal catalysts, such as perovskites [8] and nickel-based catalysts [9-11] have shown good OER activity in alkaline media and these materials are considered to be promising OER catalysts. Carbon-supported Pt and Pt-alloy catalysts have also shown excellent ORR activity. Recently, the nano Au particles have shown good ORR catalytic performance in alkaline medium [12], but $\mathrm{Pt}$ and $\mathrm{Au}$ are similarly very expensive. Among non-precious metal catalysts for the ORR, Fe- and Co-based catalysts [13-16] exhibit good activity in an acidic medium, while Mn oxides $[17,18]$, perovskites $[19,20]$, and spinels $[21,22]$ have good ORR activity in an alkaline medium. However, it also has been demonstrated that Fe-based catalyst is also active toward ORR in alkaline medium [23]. In addition, carbon-based materials also show potential to be applied for ORR applications [24]. Nevertheless, the performance of these catalysts is such that they need improvement to meet the requirements of the commercial lithium-air battery. Recently, great efforts have been made to develop effective bifunctional catalysts for the OER and the ORR, to significantly reduce the charge/discharge overpotentials of the lithium-air battery. $\mathrm{Pt}-\mathrm{Au} / \mathrm{C}$ catalyst is considered to be the current state-of-the-art bifunctional catalyst. However, Pt, Au, and other precious metals are for such catalysts to be considered as being suitable for large-scale commercial applications of the lithium-air battery [22,23]. Among the non-precious metal bifunctional catalysts, Fe-, Co-, and Mn-based oxides exhibit good bifunctional catalytic activity. Moreover, Fe, Co, and Mn are abundant and cheap. Although these catalysts have the potential for use in the lithium-air battery their current performance is relatively low and requires improvement to meet commercial requirements [24-27].

The metal-organic framework (MOF) is a new type of porous material in which the organic ligands coordinate to the metal ion centers in a bridging mode [31,32]. Compared with traditional porous materials, MOFs have high specific surface area $[33,34]$ and a readily adjustable structure and function [35]. MOFs can be used as supports or as catalysts, and the functional groups and metal ions of MOFs can be designed directly as the active sites for catalytic reactions. Although MOFs have been regarded as excellent catalytic materials [36], there have been very few reports on the use of MOFs as electrocatalysts [37-39]. Mao et al. [37] studied the ORR activity of MOF $\mathrm{Cu}^{\mathrm{II}}$-bipy-BTC in a medium of $\mathrm{pH} 6$, and found that this MOF exhibited stable activity for the ORR. In addition, a MOF-based composite (G-dye-FeP) $)_{n}$ comprising pyridine-functionalized graphene (G-dye) and an iron porphyrin (FeP) exhibited good catalytic activity for the ORR in an alkaline medium [40]. These preliminary results show that MOFs have a very significant potential as electrocatalysts, especially in ORR catalysis. However, the electrochemical performance of MOF materials and especially the relationship between structure and the ORR catalytic performance have not been studied in detail. In addition, there are few reports on MOFs applied to the OER. Hence, this work has introduced iron into MOFs and taken the advantage of the unique structures of MOFs, which both are beneficial for ORR catalysis applications. In the present work, MOF(Fe) was synthesized by a hydrothermal method using ferric nitrate as the metal ion precursor and trimesic acid as the organic ligand. The structure of the $\operatorname{MOF}(\mathrm{Fe})$ was characterized and the electrochemical performances of $\mathrm{MOF}(\mathrm{Fe})$ were investigated in an alkaline electrolyte. The results show that the MOF(Fe) has good bifunctional catalytic activity for the OER and the ORR. This work opens a new route for the development of effective non-precious metal catalysts based on MOFs for rechargeable lithium-air batteries.

\section{Experimental}

\subsection{Preparation of $\mathrm{MOF}(\mathrm{Fe})$}

$\mathrm{MOF}(\mathrm{Fe})$ was prepared by a hydrothermal process. $\mathrm{Fe}\left(\mathrm{NO}_{3}\right)_{3} \cdot 9 \mathrm{H}_{2} \mathrm{O}$ (AR, Shanghai Sinpeuo Fine Chemical Co., Ltd), 1,3,5-BTC (98\%, Aladdin Chemistry Co., Ltd.), 5 mol/L HF (AR, Shanghai Lingfeng Chemical Reagent Co., Ltd) and $\mathrm{H}_{2} \mathrm{O}$ were mixed under stirring. The molar ratio of these materials was $1.0\left(\mathrm{Fe}^{3+}\right): 0.66(1,3,5-\mathrm{BTC}): 2.0(\mathrm{HF}): 280\left(\mathrm{H}_{2} \mathrm{O}\right)$. The resulting mixture was loaded in a Teflon-lined stainless steel autoclave, which was then sealed and placed in an oven at $150{ }^{\circ} \mathrm{C}$ for $84 \mathrm{~h}$, followed by cooling to room temperature. After filtration, the residue was further purified by a two-step process.The powder sample was first purified using hot water at $80{ }^{\circ} \mathrm{C}$ for $3 \mathrm{~h}$, followed by filtration and washing and was then treated with hot ethanol at $60^{\circ} \mathrm{C}$ for $1 \mathrm{~h}$. Further filtration was carried out and the solid was washed until no colored impurities could be detected in the filtrate. The resulting solid (the MOF(Fe)) was dried at $100{ }^{\circ} \mathrm{C}$ overnight under vacuum.

\subsection{Characterization of the sample}

The powder X-ray diffraction (XRD) pattern was recorded on a D/max 2500 PC type X-ray powder diffraction with $\mathrm{Cu} K_{\alpha}$ radiation operated at $40 \mathrm{kV}$ and $100 \mathrm{~mA}$. Fourier transform infrared (FT-IR) spectra of the MOF(Fe) sample were recorded on a Nicolet 5700 FTIR spectrometer using a $\mathrm{KBr}$ powder pressed tablet with scans from 4000 to $400 \mathrm{~cm}^{-1}$. $\mathrm{N}_{2}$ adsorption-desorption isotherms and pore size distributions were obtained on an ASAP 2010C Micromeritics automatic analyzer. The specific surface area of the sample was calculated by the BET method and the pore size distribution of was determined from the desorption branch using the BJH model. Thermogravimetric analysis (TGA) was carried out on a TG 209 F3 thermoanalyzer with a heating rate of $10{ }^{\circ} \mathrm{C} / \mathrm{min}$ from room temperature to $850{ }^{\circ} \mathrm{C}$ under air. The morphology of the sample was revealed using transmission electron microscopy (TEM, JEOL JEM-2100).

\subsection{Preparation of the working electrode and the rotating disk electrode}

Preparation of the working electrode involved using $4 \mathrm{mg}$ 
MOF(Fe) and $1 \mathrm{mg}$ carbon black Super P (SP, Timcal), $50 \mu \mathrm{L}$ Nafion (5\%, DuPont) which were ultrasonically dispersed in 1 $\mathrm{mL}$ of ethanol for $30 \mathrm{~min}$, and the obtained catalyst ink (50 $\mu \mathrm{L})$ was dropped onto a $1 \times 1 \mathrm{~cm}^{2}$ carbon paper (TGP-H-060, Toray). After drying at $80{ }^{\circ} \mathrm{C}$, the working electrode was obtained.

For the preparation of the rotating disk electrode a glassy carbon (GC) electrode with geometric area of $0.196 \mathrm{~cm}^{2}$ was polished using a succession of metallographic abrasive papers and a $0.3 \mu \mathrm{m}$-alumina slurry. The solid was then rinsed with deionized water until it was clean. After drying, $10 \mu \mathrm{L}$ of the above catalyst ink was coated onto the GC electrode. After drying at $80^{\circ} \mathrm{C}$, the rotating disk electrode was obtained.

\subsection{Electrochemical measurements}

The OER and ORR catalytic activity tests were carried out in an electrochemical workstation (CHI 760E, CH Instruments, Inc.) at room temperature using a standard three-electrode system in $\mathrm{KOH}$ aqueous solution $(0.1 \mathrm{~mol} / \mathrm{L})$. The $\mathrm{KCl}$-saturated $\mathrm{Ag} / \mathrm{AgCl}$ electrode and carbon rod were used as counter electrode and reference electrode, respectively. Cyclic voltammetry was carried out between -1.0 and $0.2 \mathrm{~V}$ at a scanning speed of $50 \mathrm{mV} / \mathrm{s}$ in a $\mathrm{N}_{2}$-saturated electrolyte, until the curve was stable. Then ORR catalytic activity was tested using linear sweep voltammetry with a scanning speed of $5 \mathrm{mV} / \mathrm{s}$ in a $\mathrm{N}_{2}$ - or $\mathrm{O}_{2}$-saturated electrolyte. The ORR current using the catalyst was determined by subtracting the current in the $\mathrm{N}_{2}$-saturated electrolyte from that obtained in an $\mathrm{O}_{2}$-saturated electrolyte. The rotating disk electrode tests were performed in an $\mathrm{O}_{2}$-saturated electrolyte at rotation rates in the range of $100-2500 \mathrm{r} / \mathrm{min}$ with a scan rate of $5 \mathrm{mV} / \mathrm{s}$. The durability of catalysts for the ORR was tested using chronoamperometry at $-0.4 \mathrm{~V}$ (vs. $\mathrm{Ag} / \mathrm{AgCl}$ ) in an $\mathrm{O}_{2}$-saturated electrolyte at a rotation rate of $1600 \mathrm{r} / \mathrm{min}$. The OER was tested by linear sweep voltammetry in a $\mathrm{N}_{2}$-saturated electrolyte with scanning speed of 5 $\mathrm{mV} / \mathrm{s}$ in range of $0.2-1.0 \mathrm{~V}$ (vs. $\mathrm{Ag} / \mathrm{AgCl}$ ).

\section{Results and discussion}

\subsection{Characterization of the sample}

\subsection{1. $X R D, N_{2}$ adsorption-desorption, and TEM results}

$\mathrm{XRD}$ pattern of the as-prepared $\mathrm{MOF}(\mathrm{Fe})$ sample is shown in Fig. 1. The main diffraction peaks of the MOF(Fe) sample are

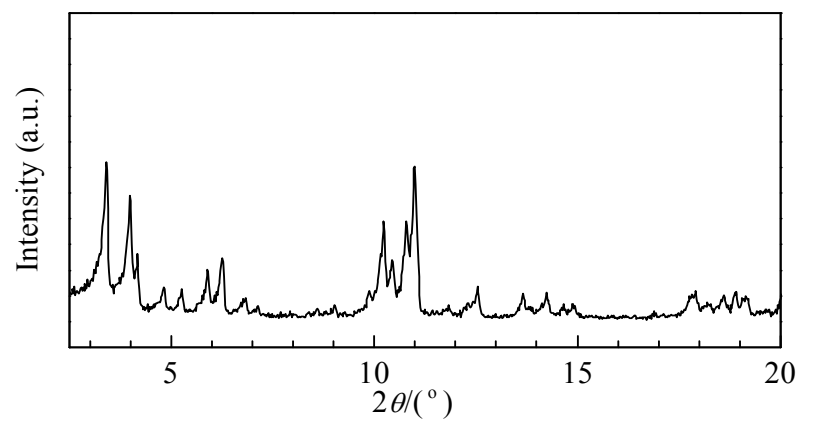

Fig. 1. XRD pattern of the $\mathrm{MOF}(\mathrm{Fe})$ sample.

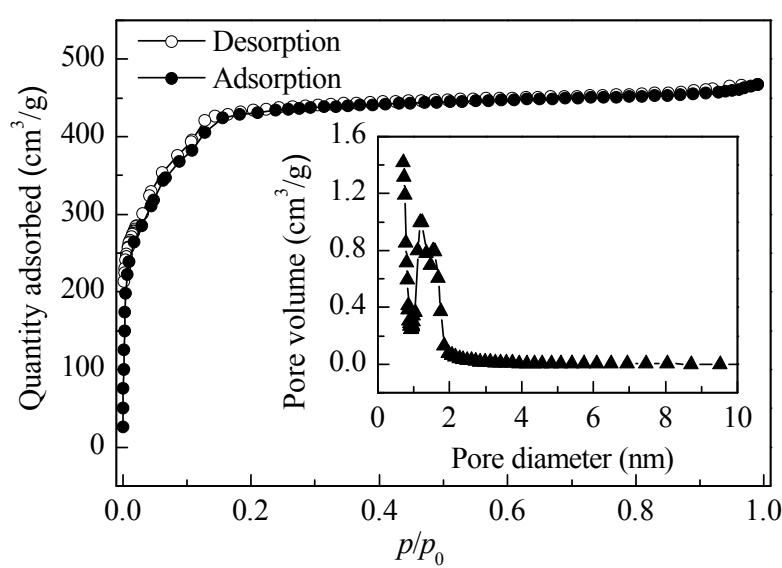

Fig. 2. $\mathrm{N}_{2}$ adsorption and desorption isotherms and pore size distribution (insert) of the MOF(Fe) sample.

observed at $2 \theta$ values of approximately $3.4^{\circ}, 4.0^{\circ}, 4.2^{\circ}, 4.8^{\circ}$, $5.3^{\circ}, 5.9^{\circ}, 6.2^{\circ}, 6.8^{\circ}, 10.2^{\circ}, 10.4^{\circ}, 10.8^{\circ}, 11.0^{\circ}, 12.6^{\circ}, 13.7^{\circ}, 14.2^{\circ}$, $17.9^{\circ}, 18.6^{\circ}, 18.9^{\circ}$, and $19.1^{\circ}$. The XRD pattern of the MOF(Fe) sample is consistent with that of the MIL- $100(\mathrm{Fe})$ prepared by Hasan et al. [38]. These results show that the MOF(Fe) exhibits well developed crystallinity.

$\mathrm{N}_{2}$ adsorption-desorption isotherms and the pore size distribution of the MOF(Fe) sample are shown in Fig. 2. $\mathrm{N}_{2}$ adsorption-desorption isotherms of the $\mathrm{MOF}(\mathrm{Fe})$ sample are of type I [42-45], indicating that the $\operatorname{MOF}(\mathrm{Fe})$ sample is a microporous material. When the relative pressure $p / p_{0}$ is in the approximate range of $0-0.15$, the amount of adsorbed $\mathrm{N}_{2}$ increases dramatically because of microporous nature of the $\operatorname{MOF}(\mathrm{Fe})$. When the relative pressure $p / p_{0} \geq 0.15$, the amount of $\mathrm{N}_{2}$ adsorbed increases slowly with an increase in $p / p_{0}$. The pore size distribution of the MOF(Fe) sample is shown in Fig. 2, where it can be seen that there is a uniform pore size distribution and that the average pore diameter is $1.2 \mathrm{~nm}$. The specific surface area calculated using the $\mathrm{N}_{2}$ desorption branch of the MOF(Fe) sample is $1600 \pm 300 \mathrm{~m}^{2} / \mathrm{g}$, and the pore volume is $0.72 \mathrm{~cm}^{3} / \mathrm{g}$. These results indicate that the $\mathrm{MOF}(\mathrm{Fe})$ sample not only has a well-developed crystallinity but also has a high specific surface area and abundant micropores.

The TEM images of the MOF(Fe) sample are shown in Fig. 3. The samples comprise irregular particles with diameters in the range $50-300 \mathrm{~nm}$. In addition, the lattice line width is about 2-3 nm, suggesting that the MOF(Fe) sample has a high crystallinity, in consistent with the XRD results.

\subsubsection{FT-IR results}

Figure 4 shows the FT-IR spectrum of the MOF(Fe) sample. The strong and broad peak located at $3410 \mathrm{~cm}^{-1}$ is assigned to

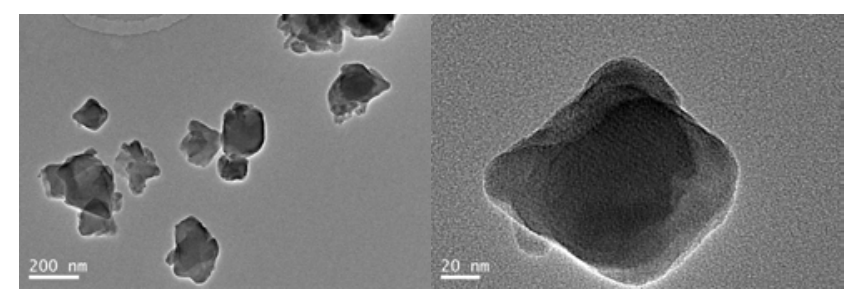

Fig. 3. TEM images of the MOF(Fe) sample. 


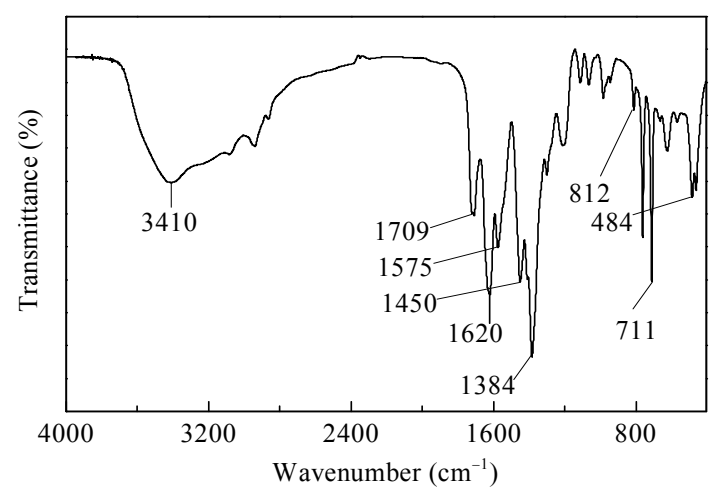

Fig. 4. FT-IR spectrum of the MOF(Fe) sample.

the $\mathrm{O}-\mathrm{H}$ vibration, indicating the presence of bound water and free water [46]. The strong peaks at 812 and $711 \mathrm{~cm}^{-1}$ are characteristic of a 1,3,5-tri substitution of the benzene ring [46]. The strong absorption peak near $1709 \mathrm{~cm}^{-1}$ can be assigned to the $\mathrm{C}=0$ stretching vibration in the $1,3,5$-BTC. The peaks observed at $1620,1575,1450$, and $1384 \mathrm{~cm}^{-1}$ have been identified as the asymmetric and symmetric vibrations of carboxyl groups, respectively. The $\Delta v\left(v_{\text {as }}(\mathrm{COO})-v_{\mathrm{s}}(\mathrm{COO})\right)$ is at 170 and $191 \mathrm{~cm}^{-1}$, suggesting that the carboxyl groups of 1,3,5-BTC coordinate to the metal ion centers in a bidentate bridging mode. These results suggest that the structure of MOF(Fe) contains the basic 1,3,5-BTC skeleton and the carboxyl groups of 1,3,5-BTC are deprotonated [47]. In addition, the peak at 484 $\mathrm{cm}^{-1}$ is related to the $\mathrm{Fe}-\mathrm{O}$ stretching vibration $[48,49]$. The results show that MOF structure is formed by the Fe ions and 1,3,5- $\mathrm{H}_{3} \mathrm{BTC}$ organic ligands.

\subsubsection{TG results}

TG curve of the MOF(Fe) sample is shown in Fig. 5. There are three stages of mass loss occurring between room temperature and $850{ }^{\circ} \mathrm{C}$. Based on FT-IR analysis, the first mass loss (about 7.5\%) in the range of room temperature to $302{ }^{\circ} \mathrm{C}$ is attributed to the release of both bound and free water molecules from within the MOF(Fe) sample [50]. When the temperature increases from 302 to $382^{\circ} \mathrm{C}$, the 1,3,5-BTC framework of $\mathrm{MOF}(\mathrm{Fe})$ begins to collapse, and the mass loss increases rapidly. When the temperature increases to $382^{\circ} \mathrm{C}$, the framework of $\mathrm{MOF}(\mathrm{Fe})$ undergoes a total collapse. With an increase in temperature from 382 to $850{ }^{\circ} \mathrm{C}, \mathrm{MOF}(\mathrm{Fe})$ completely decomposes

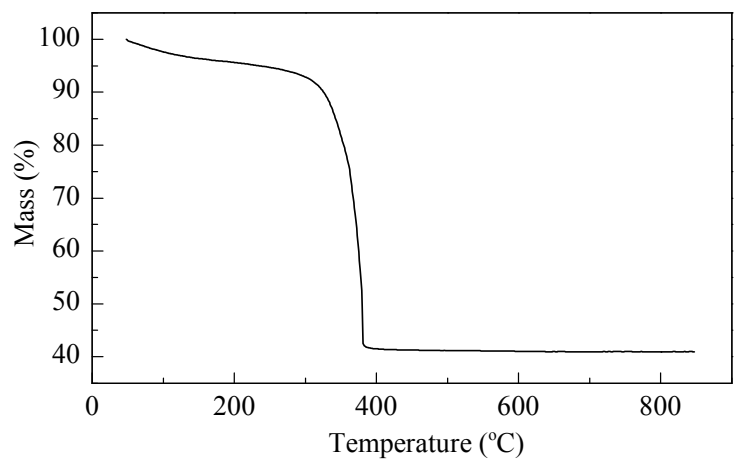

Fig. 5. TG curve of the MOF(Fe) sample. into iron oxide [50,51]. The total mass loss of the whole process is about $58.7 \%$. These results reveal that the MOF(Fe) sample has a good thermal stability below $300{ }^{\circ} \mathrm{C}$.

\subsection{The catalytic activity of $\mathrm{MOF}(\mathrm{Fe})$}

To enhance the conductivity of the $\mathrm{MOF}(\mathrm{Fe})$ sample, carbon black (Super P, SP) was mixed with MOF(Fe) during the preparation of the working electrode. The OER and ORR catalytic activities of MOF(Fe) + SP, Pt/C (20\% Pt, Johnson Matthey) and SP are shown in Figs. 6 and 7, respectively. All potentials discussed here are relative to the reference electrode of $\mathrm{Ag} / \mathrm{AgCl}$. As shown in Fig. 6, SP shows a low OER catalytic activity, and its current density is only $0.025 \mathrm{~mA} / \mathrm{cm}^{2}$ at $0.9 \mathrm{~V}$. The OER activity of $\mathrm{MOF}(\mathrm{Fe})+\mathrm{SP}$ is significantly higher and the current density is $2.30 \mathrm{~mA} / \mathrm{cm}^{2}$ at $0.9 \mathrm{~V}$ which represents a 92 -fold increase relative to that found for SP at the same potential. In addition, the catalytic activity of MOF(Fe) + SP for the OER is also much higher than that of $\mathrm{Pt} / \mathrm{C}$, because the OER current density of $\mathrm{Pt} / \mathrm{C}$ is $0.955 \mathrm{~mA} / \mathrm{cm}^{2}$ at $0.9 \mathrm{~V}$. As shown in Fig. 7, SP has a low ORR catalytic activity. Its ORR onset potential (the onset potential is defined as the potential when the current density reached $-2 \mu \mathrm{A} / \mathrm{cm}^{2}$ ) is $-0.21 \mathrm{~V}$, and its current density is only -0.08 $\mathrm{mA} / \mathrm{cm}^{2}$ at $-0.3 \mathrm{~V}$. The ORR catalytic activity of $\mathrm{MOF}(\mathrm{Fe})+\mathrm{SP}$ is significantly higher, the ORR onset potential is $-0.12 \mathrm{~V}$, and the

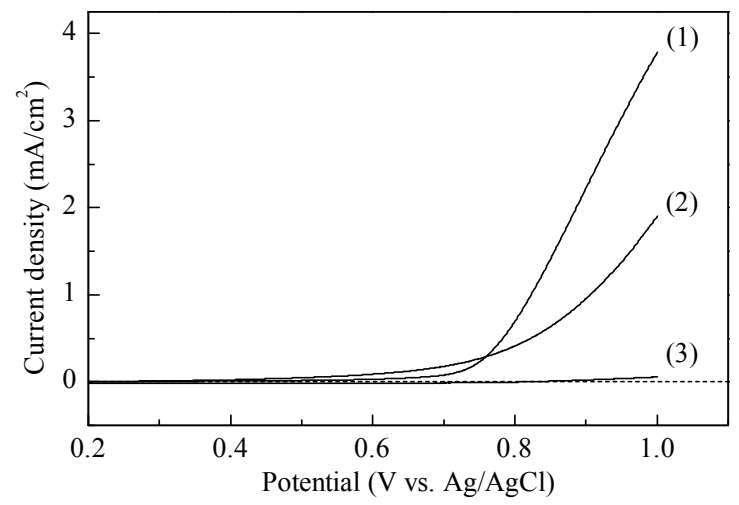

Fig. 6. The OER activities of the samples. (1) MOF(Fe) + SP; (2) Pt/C; (3) SP.

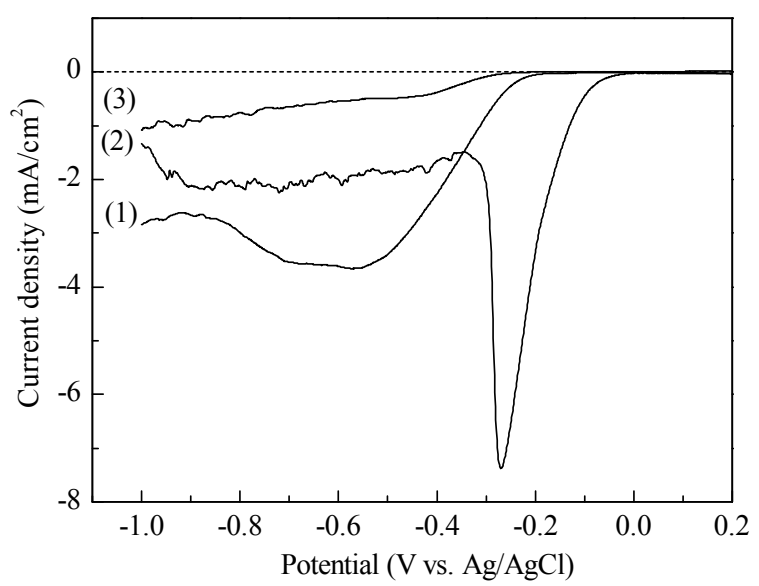

Fig. 7. The ORR activities of the samples. (1) MOF(Fe) + SP; (2) Pt/C; (3) SP. 


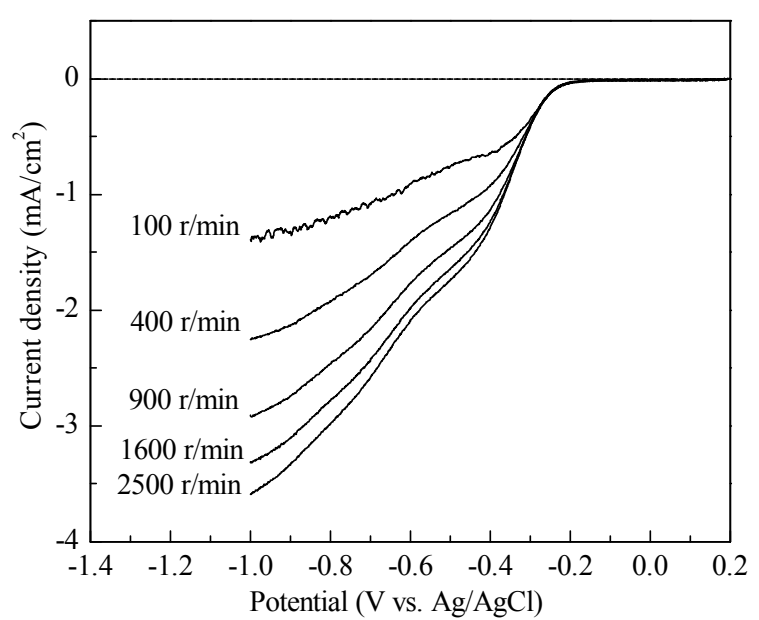

Fig. 8. Linear sweep voltammetry curves on a rotating glassy carbon electrode coated with $\mathrm{MOF}(\mathrm{Fe})+\mathrm{SP}$ at various rotation rates.

current density is $-0.93 \mathrm{~mA} / \mathrm{cm}^{2}$ at $-0.3 \mathrm{~V}$. In addition, the ORR onset potential of $\mathrm{Pt} / \mathrm{C}$ is $-0.01 \mathrm{~V}$, and the current density is $-2.09 \mathrm{~mA} / \mathrm{cm}^{2}$ at $-0.30 \mathrm{~V}$. From the structural characterization results, the high specific surface area and microporous nature of $\mathrm{MOF}(\mathrm{Fe})$ cannot only facilitate the diffusion of oxygen, but also provide a substantial reaction interface for the oxygen evolution and oxygen reduction reactions. In addition, the abundance of unsaturated coordination metal ions in the MOF(Fe) framework can provide numerous adsorption sites and catalytic sites, which are advantageous for the OER and ORR.

The activity of the MOF(Fe) + SP catalyst in the ORR was further studied using a rotating disk electrode under various rotation rates. Linear sweep voltammetry curves on a glassy carbon electrode coated with $\mathrm{MOF}(\mathrm{Fe})+\mathrm{SP}$ at various rotation rates are shown in Fig. 8. The current density increased with an increase in rotation rates because of increases in the rate of oxygen diffusion and its transport in the electrolyte.

The number of the electrons transferred per $\mathrm{O}_{2}$ molecule in ORR catalyzed by MOF(Fe) + SP can be calculated from the Koutecky-Levich (K-L) equation $[52,53]$ as follows:

$$
1 / j=1 / j_{\mathrm{k}}+1 / j_{\mathrm{d}}+1 / j_{\mathrm{f}}
$$

The thickness of Nafion film used to bind catalysts on the electrode is sufficiently small so that the resistance of the film is negligible [54], so that Eq. (1) can be approximated as Eq. (2).

$$
\begin{gathered}
1 / j=1 / j_{\mathrm{k}}+1 / j_{\mathrm{d}} \\
j_{\mathrm{d}}=0.620 n F D^{2 / 3} C_{\mathrm{o}} v^{-1 / 6} \omega^{1 / 2} \\
j_{\mathrm{k}}=n F k C_{\mathrm{o}}
\end{gathered}
$$

$j$ is the current density of experimental measurement $\left(\mathrm{mA} / \mathrm{cm}^{2}\right), j_{\mathrm{k}}$ is the kinetic current density $\left(\mathrm{mA} / \mathrm{cm}^{2}\right), j_{\mathrm{d}}$ is the diffusion-limiting current density $\left(\mathrm{mA} / \mathrm{cm}^{2}\right), j_{\mathrm{f}}$ is the diffusion-limiting current density through the Nafion film, $n$ is the number of electrons transferred per $\mathrm{O}_{2}$ molecule, $k$ is the rate constant of the ORR, $F$ is the Faraday constant $(96485 \mathrm{C} / \mathrm{mol})$, $\omega$ is the angular frequency of rotation, $C_{\mathrm{o}}$ is the concentration of oxygen in $0.1 \mathrm{~mol} / \mathrm{L} \mathrm{KOH}$ electrolyte $\left(1.21 \times 10^{-6} \mathrm{~mol} / \mathrm{cm}^{3}\right)$ [55], $D$ is the diffusion coefficient of oxygen in $0.1 \mathrm{~mol} / \mathrm{L} \mathrm{KOH}$ electrolyte $\left(1.73 \times 10^{-5} \mathrm{~cm}^{2} / \mathrm{s}\right)$ [55], and $v$ is the kinematic vis-

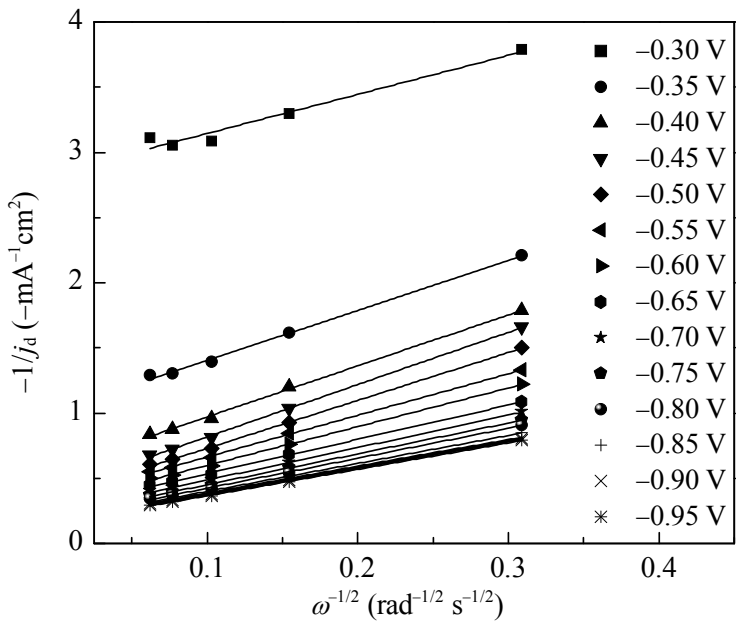

Fig. 9. Koutecky-Levich plots for the MOF(Fe) + SP.

cosity of the electrolyte $\left(0.01 \mathrm{~cm}^{2} / \mathrm{s}\right)$.

The K-L plots for ORR on MOF(Fe) + SP at different potentials are shown in Fig. 9. There is a near-linear relationship between $-1 / j_{\mathrm{d}}$ and $\omega^{-1 / 2}$, which is consistent with the K-L equation. The K-L curves do not pass through the origin in the range of -0.30 to $-0.95 \mathrm{~V}$, indicating that the ORR is a hybrid process, controlled by both diffusion and chemical kinetics in this potential range.

Usually, there are two electron transferred pathways for ORR in an alkaline electrolyte [56]:

(i) Direct four-electron pathway

$\mathrm{O}_{2}+\mathrm{H}_{2} \mathrm{O}+4 \mathrm{e}^{-} \rightarrow 4 \mathrm{OH}^{-}$

(ii) Indirect two-electron pathway

$\mathrm{O}_{2}+\mathrm{H}_{2} \mathrm{O}+2 \mathrm{e}^{-} \leftrightarrow \mathrm{HO}_{2}{ }^{-}+\mathrm{OH}^{-}$followed by either further reduction

or the decomposition reaction

$\mathrm{HO}_{2}^{-}+\mathrm{H}_{2} \mathrm{O}+2 \mathrm{e}^{-} \rightarrow 3 \mathrm{OH}^{-}$

$2 \mathrm{HO}_{2}{ }^{-} \rightarrow 2 \mathrm{OH}^{-}+\mathrm{O}_{2}$

The number of electrons transferred per $\mathrm{O}_{2}$ molecule in the ORR was calculated by the K-L equation, and was shown in Fig. 10. The mechanism of the ORR involves a two-electron pathway in the range of -0.50 to $-0.30 \mathrm{~V}$, but it shifts to a four-electron pathway when the potential increases from -0.50 to $-0.95 \mathrm{~V}$, indicating that the ORR reaction comprises a mix-

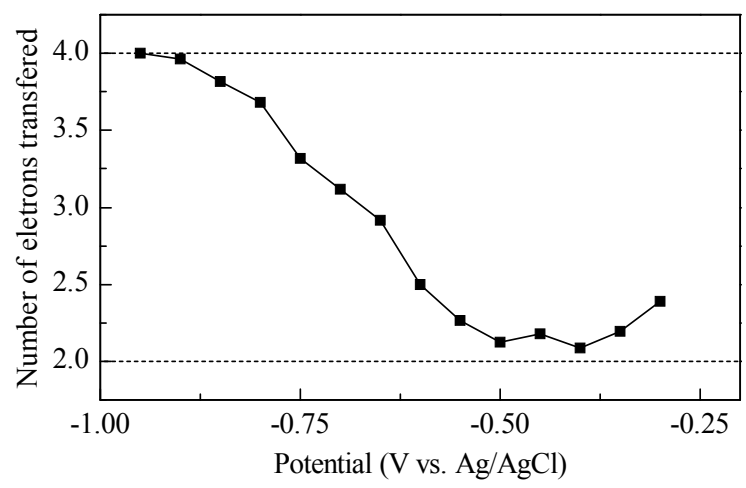

Fig. 10. The number of electrons transferred per $\mathrm{O}_{2}$ molecule at different potentials for MOF(Fe) $+\mathrm{SP}$. 


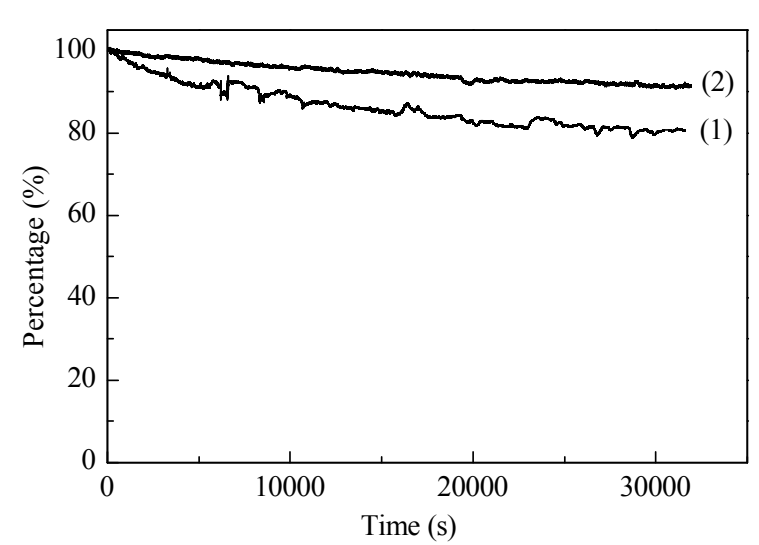

Fig. 11. The chronoamperometric responses for the ORR on samples at -0.4 V. (1) MOF(Fe) + SP; (2) Pt/C.

ture of two- and four-electron pathways in this potential range.

The ORR polarization curve under $1600 \mathrm{r} / \mathrm{min}$ was treated by the Tafel equation $\eta=a+b \lg i\left(a=\left(2.3 R T \lg i_{0}\right) / \alpha F ; b=-2.3\right.$ $R T / \alpha F$ ). It is found that the curve is consistent with the Tafel equation in the range of -0.30 to $-0.40 \mathrm{~V}$. The kinetic parameters, obtained by the Tafel equation, were $a=1.355 \mathrm{~V}, b=137$ $\mathrm{mV} / \mathrm{dec}$ and $i_{0}=1.2867 \times 10^{-10} \mathrm{~A} / \mathrm{cm}^{2}$.

The durability of MOF(Fe) + SP for the ORR was evaluated using a chronoamperometric method at $-0.40 \mathrm{~V}$ in $\mathrm{O}_{2}$-saturated $\mathrm{KOH}$ aqueous solution $(0.1 \mathrm{~mol} / \mathrm{L})$ at a rotation rate of 1600 $\mathrm{r} / \mathrm{min}$ and, for comparison, the durability of a Pt/C catalyst was also evaluated using the identical measurement system. As shown in Fig. 11, after $30000 \mathrm{~s}$, the ORR current retention rate of $\mathrm{Pt} / \mathrm{C}$ catalyst is $90 \%$, while that of MOF(Fe) + SP is $81 \%$. Although the current ORR catalytic performance of the as-prepared $\mathrm{MOF}(\mathrm{Fe})$ is lower than that of $\mathrm{Pt} / \mathrm{C}$ catalyst, it is expected that more effective electrocatalysts based on MOFs can be achieved through further research.

\section{Conclusions}

MOF(Fe) prepared by a hydrothermal method has good crystallinity, large specific surface area and high thermal stability. It exhibits good bifunctional catalytic activity for OER and ORR in an alkaline electrolyte. The high specific surface area, abundant micropores, and numerous unsaturated metal ions in MOF(Fe) are advantageous in the OER and ORR. The reaction mechanism of the ORR changes with the applied potential: the ORR takes place by a two-electron pathway in the range of -0.30 to $-0.50 \mathrm{~V}$, while a four-electron pathway is exhibited when the potential increases from -0.50 to $-0.95 \mathrm{~V}$. The results obtained strongly suggest that such catalysts can open a new route for the development of effective, low price, and environmentally friendly bifunctional catalysts for the rechargeable lithium-air battery.

\section{References}

[1] Linden D, Reddy T B. Handbook of Batteries. 3rd Ed. McGraw-Hill, 2002. 1210

[2] Girishkumar G, McCloskey B, Luntz A C, Swanson S, Wilcke W. J
Phys Chem Lett, 2010, 1: 2193

[3] Lee S W, Yabuuchi N, Gallant B M, Chen S, Kim B S, Hammond P T, S-H Y. Nature Nanotech, 2010, 5: 531

[4] Armand M, Tarascon J M. Nature, 2008, 451: 652

[5] Song M K, Park S, Alamgir F M, Cho J, Liu M. Mater Sci Eng R, 2011, 72: 203

[6] Slavcheva E, Radev I, Bliznakov S, Topalov G, Andreev P, Budevski E. Electrochim Acta, 2007, 52: 3889

[7] Hu W, Wang Y, Hu X, Zhou Y, Chen S. J Mater Chem, 2012, 22: 6010

[8] Suntivich J, May K J, Gasteiger H A, Goodenough J B, S-H Y. Science, 2011, 334: 1383

[9] Martínez W M, Fernández A M, Cano U, Sandoval J A. Int J Hydrogen Energy, 2010, 35: 8457

[10] Yeo B S, Bell A T. J Phys Chem C, 2012, 116: 8394

[11] Wu G, Li N, Dai C S, Zhou D R. Chin J Catal (武刚, 李宁, 戴长松, 周 德瑞. 催化学报), 2004, 25: 319

[12] Zhang G R, Xu B Q. Chin J Catal (张贵荣, 徐柏庆. 催化学报), 2013, 34: 942

[13] Li S, Zhu G W, Chen R X, Wang J T, Zhao W, Pan M. Chem J Chin Univ (李赏, 朱广文, 陈锐金金, 王家堂, 赵伟, 潘牧. 高等学校化学学报), 2012, 33: 1782

[14] Pérez-Alonso F J, Abdel Salam M, Herranz T, Gómez de la Fuente J L, Al-Thabaiti S A, Basahel S N, Peña M A, Fierro J L G, Rojas S. J Power Sources, 2013, 240: 494

[15] Li S, Zhou Y F, Qiu P, Pan M. Chin Sci Bull (李赏, 周彦方, 邱鹏, 潘 牧. 科学通报), 2009, 54: 881

[16] Kumar A, Singh R K, Singh H K, Srivastava P, Singh R. J Appl Polym Sci, 2013, 130: 2645

[17] Feng H, Du J, Han X P, Cheng F Y, Chen J. Chin J Inorg Chem (冯皓, 杜婧, 韩晓鹏, 程方益, 陈军. 无机化学学报), 2013, 29: 1617

[18] Moureaux F, Stevens P, Chatenet M. Electrocatal, 2013, 4: 123

[19] Zhang C, Tian J H, Shan Z Q, Chen Y X. Battery Bimonthly (张灿, 田 建华, 单忠强, 陈延禧. 电池), 2007, 37: 98

[20] Jin C, Cao X C, Zhang L Y, Zhang C, Yang R Z. J Power Sources, 2013, 241:225

[21] Ren Z W, Zhou D B, Tu S Q. Chin J Catal (任志伟, 周德璧, 屠赛琦. 催化学报), 2007, 28: 217

[22] Cheng F Y, Shen J, Peng B, Pan Y D, Tao Z L, Chen J. Nat Chem, 2011, 3: 79

[23] Yan X H, Zhang G R, Xu B Q. Chin J Catal (严祥辉, 张贵荣, 徐柏庆. 催化学报), 2013, 34: 1992

[24] Yang L J, Zhao Y, Chen S, Wu Q, Wang X Z, Hu Z. Chin J Catal (杨立 军, 赵宇, 陈盛, 吴强, 王喜章, 胡征. 催化学报), 2013, 34: 1986

[25] Zhang T, Imanishi N, Hasegawa S, Hirano A, Xie J, Takeda Y, Yamamoto 0, Sammes N.J Electrochem Soc, 2008, 155: A965

[26] Gasteiger H A, Kocha S S, Sompalli B, Wagner F T. Appl Catal B, 2005, 56: 9

[27] Shao Y Y, Liu J, Wang Y, Lin Y H.J Mater Chem, 2009, 19: 46

[28] Antolini E, Gonzalez E R. Solid State Ionics, 2009, 180: 746

[29] Antolini E, Gonzalez E R. Appl Catal A, 2009, 365: 1

[30] Antolini E. Appl Catal B, 100: 413

[31] Hoskins B F, Robson R.J Am Chem Soc, 1989, 111: 5962

[32] Hoskins B F, Robson R. J Am Chem Soc, 1990, 112: 1546

[33] Furukawa H, Ko N, Go Y B, Aratani N, Choi S B, Choi E, Yazaydin A O, Snurr R Q, O'Keeffe M, Kim J, Yaghi O M. Science, 2010, 329: 424

[34] Xuan W, Zhu C, Liu Y, Cui Y. Chem Soc Rev, 2012, 41: 1677

[35] Carné A, Carbonell C, Imaz I, Maspoch D. Chem Soc Rev, 2011, 40: 291

[36] Morozan A, Jaouen F. Energy Environ Sci, 2012, 5: 9269

[37] Mao J J, Yang L F, Yu P, Wei X W, Mao L Q. Electrochem Commun, 2012, 19: 29

[38] Babu K F, Kulandainathan M A, Katsounaros I, Rassaei L, Burrows 


\title{
Graphical Abstract
}

Chin. J. Catal., 2014, 35: 185-195 doi: 10.1016/S1872-2067(12)60729-3

\section{Preparation of MOF(Fe) and its catalytic activity for oxygen reduction reaction in an alkaline electrolyte}

Guoqiang Song, Zhiqing Wang, Liang Wang, Guoru Li, Minjian Huang,

Fengxiang Yin*

Changzhou University;

Beijing University of Chemical Technology

MOF(Fe) was synthesized by a hydrothermal method and shows excellent bifunctional catalytic activity for the oxygen evolution reaction (OER)and oxygen reduction reaction (ORR) in an alkaline electrolyte.

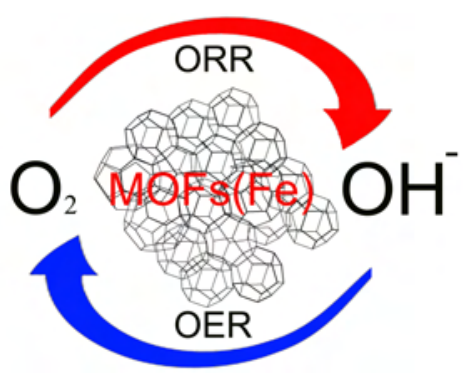

A D, Raithby P R, Marken F. Electrochem Commun, 2010, 12: 632

[39] Yang L F, Kinoshita S, Yamada T, Kanda S, Kitagawa H, Tokunaga M, Ishimoto T, Ogura T, Nagumo R, Miyamoto A, Koyama M. Angew Chem Int Ed, 2010, 122: 5476

[40] Jahan M, Bao Q and Loh K P.J Am Chem Soc, 2012, 134: 6707

[41] Hasan Z, Jeon J, Jhung S H. J Hazard Mater, 2012, 209-210: 151

[42] Yang R T. Adsorbents: Fundamentals and Applications. New York: Wiley-Interscience, 2003

[43] Sing K S W, Everett D H, Haul R A W, Moscou L, Pierotti R A, Rouquérol J, Siemieniewska T. Pure Appl Chem, 1985, 57: 603

[44] Wang X Y. Catalyst Characterization. Shanghai: East China University of Science and Technology Press (王幸宜. 催化剂表征. 上海: 华东理工大学出版社), 2008.9

[45] Kurfiřtová L, Seo Y K, Hwang Y K, Chang J S, Čejka J. Catal Today, 2012, 179: 85

[46] Pan T Y, Zhang Y L, Su K M. Spectral Analysis Method. Shanghai: East China University of Science and Technology Press (潘铁英, 张 玉兰, 苏克曼. 波谱解析法. 第二版. 上海: 华东理工大学出版社), 2009. 7
[47] Zhang T, Lu Y, Li Y, Zhang Z, Chen W, Fu H, Wang E. Inorg Chim Acta, 2012, 384: 219

[48] Nakamoto K. Infrared Spectra of Inorganic and Coordination Compounds. New York: Wiley, 1963. 217

[49] Dhakshinamoorthy A, Alvaro M, Garcia H. J Catal, 2012, 289: 259

[50] Horcajada P, Surblé S,Serre C, Hong D Y, Seo Y K, Chang J S, Grenèche J M, Margiolaki I, Férey G. Chem Commun, 2007, (27): 2820

[51] Canioni R, Roch-Marchal C, Sécheresse F, Horcajada P, Serre C, Hardi-Dan M, Férey G, Grenèche J M, Lefebvre F, Chang J S, Hwang Y K, Lebedev O, Turner S, Tendeloo G V. J Mater Chem, 2011, 21: 1226

[52] Higuchi E, Uchida H, Watanabe M. J Electroanal Chem, 2005, 583 : 69

[53] Kruusenberg I, Alexeyeva N, Tammeveski K. Carbon, 2009, 47: 651

[54] Colon-Mercado H R, Popov B N.J Power Sources, 2006, 155: 253

[55] Lai L, Potts J R, Zhan D, Wang L, Poh C K, Tang C, Gong H, Shen Z X, Lin J, Ruoff R S. Energy Environ Sci, 2012, 5: 7936

[56] Jin C, Cao X C, Zhang L Y, Zhang C, Yang R Z. J Power Sources, 2013, 241: 225

\section{$\operatorname{MOF}(\mathrm{Fe})$ 的制备及其氧气还原催化性能}

\author{
宋国强，王志清 ${ }^{\mathrm{a}}$ ，王 亮 ${ }^{\mathrm{c}}$, 李国儒 ${ }^{\mathrm{c}}$, 黄敏建 ${ }^{\mathrm{c}}$, 银凤翔 b,c, * \\ $\mathrm{a}$ 常州大学制药与生命科学学院, 江苏常州213164 \\ ${ }^{\mathrm{b}}$ 北京化工大学有机无机复合材料国家重点实验室, 北京100029 \\ 北京化工大学常州先进材料研究院, 江苏常州 213164
}

\begin{abstract}
摘要: 以硝酸铁为金属离子前驱体、均苯三甲酸为有机配体, 采用水热法合成了金属有机骨架 $\mathrm{MOF}(\mathrm{Fe})$ 催化剂, 应用X射线衍射、 $\mathrm{N}_{2}$ 吸附-脱附、透射电镜、红外光谱和热重等方法对催化剂的结构进行了表征, 并采用循环伏安法测试了催化剂在碱性电解质中 的氧气还原 $(\mathrm{ORR})$ 催化性能, 同时也采用旋转圆盘电极进一步研究了催化剂的ORR的动力学行为. 结果表明, 所制 MOF(Fe)具有 很好的晶型结构、大比表面积、丰富的微孔以及较高的热稳定性. 且表现出很好的ORR催化活性. ORR的反应历程随电位的改变 而改变: 电位在 -0.3 到 $0.50 \mathrm{~V}$ 范围内, $\mathrm{ORR}$ 为 2 电子途径; 随着电位从- $0.50 \mathrm{~V}$ 升至 $-0.95 \mathrm{~V}, \mathrm{ORR}$ 从 2 电子向 4 电子途径转变. 另外, 该催化剂在碱性电解质中也表现出较好的氧气析出(OER)催化性能, 这为制备用于ORR和OER的高效非贵金属催化剂提供了新 的途径.
\end{abstract}

关键词: 金属有机骨架; 水热法; 氧气还原反应; 氧气析出反应; 锂-空气电池

收稿日期: 2013-07-31. 接受日期: 2013-10-15. 出版日期: 2014-02-20.

*通讯联系人. 电话: (010)64412054; 传真: (010)64419619; 电子信箱: yinfx@mail.buct.edu.cn 基金来源: 国家自然科学基金(21276018); 北京市优秀人才培养资助项目(2012D009016000003); 江苏省自然科学基金 (BK2012596); 常州市科技计划(工业支撑)项目(CE20120034).

本文的英文电子版由Elsevier出版社在ScienceDirect上出版(http://www.sciencedirect.com/science/journal/18722067). 


\section{1. 前言}

锂-空气电池的理论能量密度高达 $11140 \mathrm{Wh} / \mathrm{kg}$, 与 汽油-氧体系相当 ${ }^{[1-3]}$, 是目前高性能锂离子电池的 10 倍 多 ${ }^{[2-4]}$. 另外, 它还具有体系轻、无毒无污染、价格低廉 等优点, 是一种极具应用前景的二次电池. 然而, 锂-空 气电池充电过程发生的氧气析出反应(OER)和放电过程 发生的氧气还原反应(ORR)都是慢反应, 导致较大的充 放电过电压, 降低了电池的充放电效率和循环性能, 使 得锂-空气电池目前难以作为二次电池应用. 双功能催 化剂 ${ }^{[5]}$ 可以加快OER和ORR的反应速率, 既能减小充电 过电位、降低充电电压, 又能减小放电过电位、提高放 电平台, 从而大大提高锂-空气电池的充放电效率和循 环性能, 为实现可充电锂-空气电池商业化提供一条有 效途径.

目前, $\mathrm{IrO}_{2}$ 被认为是最好的OER催化剂, 但 $\mathrm{Ir}$ 是非常 稀有和昂贵的金属, 甚至比Pt还贵 ${ }^{[6,7]}$, 难以满足商业化 的要求. 最近, 一些非贵金属催化剂, 如钙铁矿 ${ }^{[8]}$ 、镍基 催化剂 ${ }^{[9-11]}$ 等在碱性介质中表现出较好的OER活性, 被 认为是有望替代贵金属的析氧催化剂. 碳负载的Pt及其 合金催化剂具有最好的ORR活性, 近来人们还论证了纳 米尺寸的金颗粒在碱性电解质中具有非常好的 ORR活 性 ${ }^{[12]}$, 但是Pt和 $A u$ 的价格昂贵. 在非贵金属的ORR催化 剂中, $\mathrm{Fe}$ 和 $\mathrm{Co}$ 基催化剂 ${ }^{[13-16]}$ 在酸性介质中具有较好的 ORR 活性, 而 $\mathrm{Mn}$ 氧化物 ${ }^{[17,18]}$ 、钲钛矿 ${ }^{[19,20]}$ 以及尖晶 石 ${ }^{[21,22]}$ 在碱性介质中具有较好的ORR活性, 此外, 部分 $\mathrm{Fe}$ 基催化剂在碱性电解质中也具有很好的 ORR 活性 ${ }^{[23]}$. 不仅如此, 碳材料在ORR的催化中同样显示出了巨大的 潜力 ${ }^{[24]}$. 但是这些催化剂的活性都还有待于进一步提 高, 以满足商业化的要求. 近年来围绕研发高效双功能 催化剂、降低充放电过电压做了大量的研究工作. $\mathrm{Pt}-\mathrm{Au} / \mathrm{C}$ 催化剂目前被认为是所研发的双功能催化剂中 性能最好的, 但是 Pt, $\mathrm{Au}$ 等贵金属价格昂贵, 不适合可充 电锂-空气电池的大规模商业化应用 ${ }^{[25,26]}$. 在研发的非 贵金属双功能催化剂中, $\mathrm{Fe}, \mathrm{Co}$ 和 $\mathrm{Mn}$ 等过渡金属氧化物 表现出很好的双功能催化活性, 且储量丰富、价格低廉, 但仍难以满足可充电锂-空气电池的商业化要求, 还有 待于进一步提高其性能 ${ }^{[27-30]}$.

金属有机骨架 $(\mathrm{MOFs})$ 是由金属离子与有机配体相 互桥联形成的一种新型多孔材料 ${ }^{[31,32]}$. 与现有多孔材料 相比, MOFs 具有高比表面积 ${ }^{[33,34]}$, 结构和功能可调 ${ }^{[35]}$ 等 显著优点; 它不仅可用作催化剂载体, 而且由于其结构
和功能具有可调性, 可以设计将金属离子或MOFs上的 官能团直接作为催化反应的活性位, 因此, MOFs 是一种 非常优秀的催化材料 ${ }^{[36]}$. 目前, 将MOFs材料用作电催 化剂的研究刚刚起步 ${ }^{[37-39]}$. Mao等 ${ }^{[37]}$ 在 $\mathrm{pH}$ 为 6 的介质中 测试了 MOF $\mathrm{Cu}^{\mathrm{II}}{ }^{-}-\mathrm{bipy}-\mathrm{btc}$ 的 ORR 活性, 结果表明, 该 MOFs 材料表现出稳定的ORR催化活性. 另外, 报道了 一种由吡啶功能化的石墨烯(G-dye)和卟啉铁(FeP)组装 的石墨烯一金属卟啉金属有机骨架复合材料 (G-dye-FeP) $n$, 这种基于MOFs的复合材料在碱性介质中 具有较好的ORR活性 ${ }^{[40]}$. 这些初步的研究表明, MOFs 具有用于电催化剂, 特别是ORR催化剂的巨大潜力. 但 是对MOFs 材料的电化学特性, 特别是MOFs 结构与 ORR 催化性能的关系研究不够深入, 尤其很少有将MOFs用 于氧气析出反应的报道. 本工作将 $\mathrm{Fe}$ 元素引入到 $\mathrm{MOF}$ 结构中, 并利用MOF特有的结构, 从而达到较好的ORR 催化活性. 本文以硝酸铁为金属离子前驱体, 均苯三甲 酸为有机配体, 通过水热法制备了 $\mathrm{MOF}(\mathrm{Fe})$, 并对样品 进行了表征, 并在碱性电解质中测试了 $\mathrm{MOF}(\mathrm{Fe})$ 的电化 学性能, 结果表明, $M O F(F e)$ 具有很好的OER 和ORR双 功能催化活性, 该工作为制备用于可充电锂-空气电池 的高效非贵金属双功能催化剂提供了新的途径.

\section{2. 实验部分}

\section{1. 催化剂制备}

$\mathrm{Fe}\left(\mathrm{NO}_{3}\right)_{3} \cdot 9 \mathrm{H}_{2} \mathrm{O}(\mathrm{AR}$, 上海新宝精细化工厂)、 $1,3,5-\mathrm{H}_{3} \mathrm{BTC}(98 \%$, 阿拉丁科技有限公司)、 $5 \mathrm{~mol} / \mathrm{L}$ 的 $\mathrm{HF}(\mathrm{AR}$, 上海凌峰化学试剂有限公司)、去离子水, 以摩 尔比 1:0.66:2:280混合并充分搅拌后, 移入反应釜中, 密 闭后置于电热鼓风烘箱中, 在 $150{ }^{\circ} \mathrm{C}$ 保持 $84 \mathrm{~h}$, 然后自然 冷却至室温, 过滤后进行两步纯化: 首先在 $80^{\circ} \mathrm{C}$ 去离子 水中煮 $3 \mathrm{~h}$, 过滤, 洗涤; 然后在 $60^{\circ} \mathrm{C}$ 乙醇中煮 $1 \mathrm{~h}$, 抽滤, 洗涤直至母液为无色. 最后在真空干燥箱中经 $100{ }^{\circ} \mathrm{C}$ 干 燥, 得到 $\mathrm{MOF}(\mathrm{Fe})$ 样品.

\section{2. 催化剂表征}

$\mathrm{X}$ 射线衍射(XRD)分析采用 $\mathrm{D} / \max 2500 \mathrm{PC}$ 型X射线 粉末衍射仪, $\mathrm{Cu}$ 靶 $K_{\alpha}$ 射线, 管电压 $40 \mathrm{kV}$, 管电流 $100 \mathrm{~mA}$. 傅里叶变换红外光谱(FT-IR)分析采用美国Nicolet公司 的 5700 型傅里叶红外光谱仪, $\mathrm{KBr}$ 压片, 扫描范围为 4000-400 $\mathrm{cm}^{-1}$. $\mathrm{N}_{2}$ 吸附-脱附等温线和孔径分布在美国 Microméritics公司的ASAP 2010C上测定, 样品比表面积 用BET法计算, 孔径分布采用BJH模型根据脱附曲线计 算. 采用德国NETZSCH公司的TG 209 F3 热重分析仪进 
行样品的热重(TG)分析, 在空气条件下, 以 $10^{\circ} \mathrm{C} / \mathrm{min}$ 升 温研究催化剂的热稳定性. 样品的透射电镜(TEM)照片 在日本JEOL公司JEM-2100透射电子显微镜上获得.

\section{3. 工作电极和旋转圆盘电极制备}

称取 $4 \mathrm{mg}$ 的 $\mathrm{MOF}(\mathrm{Fe})$ 和 $1 \mathrm{mg}$ 的导电炭黑Super P(SP, Timcal), 然后加入 $1 \mathrm{ml}$ 无水乙醇和 $50 \mu \mathrm{l}$ 的 Nafion溶液 (5\%, DuPont), 超声 $30 \mathrm{~min}$ 得到混合液, 再移取 $50 \mu \mathrm{l}$ 混合 液滴在 $1 \times 1 \mathrm{~cm}^{2}$ 碳纸(TGP-H-060, Toray)上, 在 $80^{\circ} \mathrm{C}$ 干 燥后, 制得工作电极.

玻碳电极(直径 $5 \mathrm{~mm}$ )采用金相砂纸、粒度为 $0.3 \mu \mathrm{m}$ 的 $\mathrm{Al}_{2} \mathrm{O}_{3}$ 打磨抛光, 冲洗干净并干燥后, 分别移取上述混 合液 $10 \mu \mathrm{l}$ 滴于玻碳电极上, 在 $80^{\circ} \mathrm{C}$ 干燥后制得旋转圆 盘电极.

\section{4. 电化学测试}

OER 和ORR催化活性测试都是在电化学工作站 (CHI 760E, 上海辰华仪器有限公司)上进行. 采用传统 三电极体系: 碳棒为辅助电极, $\mathrm{Ag} / \mathrm{AgCl}$ 电极为参比电 极, 电解液为 $0.1 \mathrm{~mol} / \mathrm{L}$ 的 $\mathrm{KOH}$ 水溶液. 在电化学性能测 试前, 工作电极在 $\mathrm{N}_{2}$ 饱和的 $\mathrm{KOH}$ 电解质 $(0.1 \mathrm{~mol} / \mathrm{L})$ 中, 以 $50 \mathrm{mV} / \mathrm{s}$ 的扫描速度在 -1.0 至 $0.2 \mathrm{~V}$ (vs. $\mathrm{Ag} / \mathrm{AgCl}$ ) 的电 压范围内, 用循环伏安法扫描直至曲线稳定. 然后分别 在 $\mathrm{N}_{2}$ 和 $\mathrm{O}_{2}$ 饱和的电解质中, 以 $5 \mathrm{mV} / \mathrm{s}$ 的扫描速度, 采用 线性扫描伏安法测试样品的ORR性能. $\mathrm{O}_{2}$ 饱和电解质 中测得的电流与 $\mathrm{N}_{2}$ 饱和电解质中测得的电流之间的差 值被确定为催化剂的ORR电流. 旋转圆盘电极测试在上 述相同体系中进行, 扫描范围为 $-1.0-0.2 \mathrm{~V}$ (vs. $\mathrm{Ag} / \mathrm{AgCl}$ ), 扫描速度为 $5 \mathrm{mV} / \mathrm{s}$, 旋转圆盘转速为 100,400 , 900,1600 和 $2500 \mathrm{r} / \mathrm{min}$. 保持电位为 $-0.4 \mathrm{~V}$ (vs. Ag/ $\mathrm{AgCl}$ ), 旋转圆盘转速为 $1600 \mathrm{r} / \mathrm{min}$, 在 $\mathrm{O}_{2}$ 饱和的 $\mathrm{KOH}$ 水 溶液 $(0.1 \mathrm{~mol} / \mathrm{L})$ 中, 采用计时电流法测试催化剂的 $\mathrm{ORR}$ 活性保持率. OER活性是在 $\mathrm{N}_{2}$ 饱和电解质中, 采用线性 扫描伏安法进行测试, 电压扫描范围 $0.2-1.0 \mathrm{~V}$ (vs. $\mathrm{Ag} / \mathrm{AgCl})$, 扫描速度 $5 \mathrm{mV} / \mathrm{s}$.

\section{3. 结果与讨论}

\section{1. 催化剂表征}

\subsubsection{XRD, $\mathrm{N}_{2}$ 吸-脱附和TEM结果}

图 1 为 $\mathrm{MOF}(\mathrm{Fe})$ 催化剂的 $\mathrm{XRD}$ 谱, 在 $3.4^{\circ}, 4.0^{\circ}, 4.2^{\circ}$, $4.8^{\circ}, 5.3^{\circ}, 5.9^{\circ}, 6.2^{\circ}, 6.8^{\circ}, 10.2^{\circ}, 10.4^{\circ}, 10.8^{\circ}, 11.0^{\circ}, 12.6^{\circ}$, $13.7^{\circ}, 14.2^{\circ}, 17.9^{\circ}, 18.6^{\circ}, 18.9^{\circ}$ 和 $19.1^{\circ}$ 出现了 $\mathrm{MOF}(\mathrm{Fe})$ 的 主要衍射峰, 与文献[41]合成的MIL-100(Fe)的衍射峰的 位置基本吻合, 表明合成的 $M O F(F e)$ 具有很好的晶相结
构. 图 2 为催化剂的 $\mathrm{N}_{2}$ 吸附-脱附等温线以及孔径分布 图. 由图可见, $\mathrm{MOF}(\mathrm{Fe})$ 的 $\mathrm{N}_{2}$ 吸附-脱附等温线属于典型 的 I 型 ${ }^{[42-45]}$, 表明 $\mathrm{MOF}(\mathrm{Fe})$ 为微孔材料. 当相对压力 $p / p_{0}$ 在0-0.15范围内, $\mathrm{N}_{2}$ 吸附量急剧增加, 这主要是由于在此 相对压力范围内, $\mathrm{N}_{2}$ 主要被吸附在 $\mathrm{MOF}(\mathrm{Fe})$ 的微孔中, $\mathrm{MOF}(\mathrm{Fe})$ 丰富的微孔结构提供了众多 $\mathrm{N}_{2}$ 吸附位点; 当相 对压力 $p / p_{0} \geqslant 0.15$ 时, 随着 $p / p_{0}$ 的增加, $\mathrm{N}_{2}$ 吸附量缓慢上 升, 这是因为 $\operatorname{MOF}(\mathrm{Fe})$ 的微孔内部已几乎全部被 $\mathrm{N}_{2}$ 填充, 此时 $\mathrm{N}_{2}$ 吸附主要发生在 $\mathrm{MOF}(\mathrm{Fe})$ 的外表面, 而外表面较 小, 可提供的 $\mathrm{N}_{2}$ 吸附位点较少, 因此对 $\mathrm{N}_{2}$ 吸附的增加量 较小. 另外, 从 $\operatorname{MOF}(\mathrm{Fe})$ 的孔径分布图可以看出, $\mathrm{MOF}(\mathrm{Fe})$ 的孔径分布基本均一, 平均孔径为 $1.2 \mathrm{~nm}$. 可 计算得到 $\mathrm{MOF}(\mathrm{Fe})$ 的比表面积为 $1655 \pm 300 \mathrm{~m}^{2} / \mathrm{g}$, 孔容 为 $0.72 \mathrm{~cm}^{3} / \mathrm{g}$. 由此可见, 所制 $M O F(F e)$ 不仅具有很好的 晶相结构, 而且具有高的比表面积以及丰富的微孔结构.

图 3 为 $\mathrm{MOF}(\mathrm{Fe})$ 催化剂的 TEM照片. 可以看到, $\mathrm{MOF}(\mathrm{Fe})$ 的颗粒几何外形不规整, 大小约为 50-300 nm. 还可以看到, $\mathrm{MOF}(\mathrm{Fe})$ 的晶格线宽度大约在 $2-3 \mathrm{~nm}$, 表 明其具有很好的晶相结构, 与XRD结果一致.

\subsubsection{FT-IR结果}

图4为催化剂的FT-IR谱. 由图可知, 在 $3410 \mathrm{~cm}^{-1}$ 附 近出现强而宽的吸收峰, 可以归属为水分子中 $\mathrm{O}-\mathrm{H}$ 键的 伸缩振动, 表明 $\mathrm{MOF}(\mathrm{Fe})$ 结构中含有配位水或吸附水 ${ }^{[46]}$. 在 812 和 $711 \mathrm{~cm}^{-1}$ 处出现的吸收峰可以归属为苯环上 1,3,5-三取代的特征吸收峰 ${ }^{[46]}$; 在 $1709 \mathrm{~cm}^{-1}$ 处的强吸收 峰可以归属于 $1,3,5-\mathrm{BTC}$ 结构中的 $\mathrm{C}=\mathrm{O}$ 的伸缩振动峰; 在 $1620,1575,1450$ 和 $1384 \mathrm{~cm}^{-1}$ 处的吸收峰分别可以归 属为 $1,3,5-\mathrm{BTC}$ 结构中的 $-\mathrm{CO}_{2}$ 不对称伸缩振动和对称伸 缩振动; 由 $\Delta v\left(v_{\mathrm{as}}(\mathrm{COO})-v_{\mathrm{s}}(\mathrm{COO})\right)$ 为 170 和 $191 \mathrm{~cm}^{-1}$, 可 知每个 1,3,5-BTC 的羧酸基团以双齿配位的. 可见, $\mathrm{MOF}(\mathrm{Fe})$ 结构中含有 1,3,5-BTC 的基本骨架, 并且 1,3,5- $\mathrm{H}_{3} \mathrm{BTC}$ 配体中的羧基均已去质子化 ${ }^{[47]}$. 另外, 在 $484 \mathrm{~cm}^{-1}$ 处的吸收峰可以归属为 $\mathrm{Fe}-\mathrm{O}$ 键拉伸振动 ${ }^{[48,49]}$. 上述结果表明, $\mathrm{Fe}$ 离子和有机配体 $1,3,5-\mathrm{H}_{3} \mathrm{BTC}$ 形成了 金属有机骨架结构.

\subsubsection{TG结果}

图 5 为催化剂的 $\mathrm{TG}$ 曲线. 由图可见, $\mathrm{MOF}(\mathrm{Fe})$ 在室 温至 $850{ }^{\circ} \mathrm{C}$ 范围内出现三次失重: 室温至 $302{ }^{\circ} \mathrm{C}$ 时, $\mathrm{MOF}(\mathrm{Fe})$ 失重了 $7.5 \%$, 结合FT-IR结果可知, 该阶段的失 重可归结为 $\operatorname{MOF}(\mathrm{Fe})$ 中的吸附水和配位水脱附 ${ }^{[50]}$; 当温 度从 302 升至 $382{ }^{\circ} \mathrm{C}$ 时, $\mathrm{MOF}(\mathrm{Fe})$ 的骨架 $1,3,5-\mathrm{BTC}$ 开始 分解, 晶格结构开始坍塌, 失重量急剧增加; 至 $382{ }^{\circ} \mathrm{C}$ 
时, $\mathrm{MOF}(\mathrm{Fe})$ 骨架彻底坍塌; 从 $382{ }^{\circ} \mathrm{C}$ 升到 $850{ }^{\circ} \mathrm{C}$ 过程 中, $\operatorname{MOF}(\mathrm{Fe})$ 彻底分解为铁的氧化物 ${ }^{[50,51]}$, 整个过程总重 量损失为 $58.7 \%$. 可以看出, 所制 $\mathrm{MOF}(\mathrm{Fe})$ 在 $300^{\circ} \mathrm{C}$ 以下 具有很好的热稳定性.

\section{2. $\operatorname{MOF}(\mathrm{Fe})$ 催化性能}

为了增强 $\mathrm{MOF}(\mathrm{Fe})$ 的导电性, 在制备工作电极的时 候, 采用导电炭黑Super $\mathrm{P}(\mathrm{SP})$ 与 $\mathrm{MOF}(\mathrm{Fe})$ 混合来增加导 电性. 图 6 和图 7 分别 是 $\mathrm{MOF}(\mathrm{Fe})+\mathrm{SP}, \mathrm{Pt} / \mathrm{C}(20 \% \mathrm{Pt}$, Johnson Matthey)和SP的OER和ORR催化活性结果. 本 文中, 除有特别说明外, 所讨论的电位是指相对于参比 电极 $\mathrm{Ag} / \mathrm{AgCl}$ 的电位. 由图6可知, SP具有很低的OER催 化活性, 当电位为 $0.9 \mathrm{~V}$ 时电流密度仅为 $0.025 \mathrm{~mA} / \mathrm{cm}^{2}$; 而 $\mathrm{MOF}(\mathrm{Fe})+\mathrm{SP}$ 的 $\mathrm{OER}$ 催化活性显著提高, 当电位为 0.9 $\mathrm{V}$ 时电流密度高达 $2.30 \mathrm{~mA} / \mathrm{cm}^{2}$, 是 $\mathrm{SP}$ 在该电位下电流密 度的92倍. 另外, $\mathrm{MOF}(\mathrm{Fe})+\mathrm{SP}$ 的OER活性明显高于 $\mathrm{Pt} / \mathrm{C}$, 因为在电位为 $0.9 \mathrm{~V}$ 时, $\mathrm{Pt} / \mathrm{C}$ 的 OER 电流密度为 0.955 $\mathrm{mA} / \mathrm{cm}^{2}$. 由图7可见, SP的ORR催化活性也很低, 它的起 始电位(电流密度达到 $-2 \mu \mathrm{A} / \mathrm{cm}^{2}$ 时的电位) 为 $-0.21 \mathrm{~V}$, 在 $-0.3 \mathrm{~V}$ 时电流密度仅为 $-0.08 \mathrm{~mA} / \mathrm{cm}^{2}$. 而 $\mathrm{MOF}(\mathrm{Fe})+\mathrm{SP}$ 的 起始电位为 $-0.12 \mathrm{~V}$, 在 $-0.3 \mathrm{~V}$ 时电流密度为 -0.93 $\mathrm{mA} / \mathrm{cm}^{2} . \mathrm{Pt} / \mathrm{C}$ 的起始电位为 $-0.01 \mathrm{~V}$, 在 $-0.3 \mathrm{~V}$ 时电流密 度为 $-2.09 \mathrm{~mA} / \mathrm{cm}^{2}$. 这些结果表明, 所制 $\mathrm{MOF}(\mathrm{Fe})$ 在碱 性电解质中表现出较好的 OER 和ORR双功能催化活性. 由前文可知, $M O F(F e)$ 具有很高的比表面积和丰富的微 孔结构, 不仅有利于氧气的扩散和传输, 而且可以为氧 析出和氧还原反应提供更大的反应界面; 另外由于 $\mathrm{MOF}(\mathrm{Fe})$ 骨架中的丰富不饱和配位的金属离子可以提 供众多的反应物吸附位点和催化活性位, 进而加速OER 和ORR反应.

为了进一步研究 $M O F(F e)$ 催化剂的 $O R R$ 反应的动 力学行为, 进行了不同转速下的旋转圆盘电极测试. 图8 为 $\mathrm{MOF}(\mathrm{Fe})$ 催化剂在旋转圆盘电极不同转速下的线性 扫描伏安曲线. 由图可知, 随着转速的增大, 电流密度增 大. 这是由于当旋转圆盘的转速增大时, 有利于氧气在 电解液中的扩散和传输.

通过 Koutecky-Levich (K-L) 方 程 ${ }^{[52,53]}$ 可以对 $\mathrm{MOF}(\mathrm{Fe})$ 催化的ORR反应的电子转移数进行计算, 计算 方程式如下:

$$
1 / j=1 / j_{\mathrm{k}}+1 / j_{\mathrm{d}}+1 / j_{\mathrm{f}}
$$

由于电极中粘合催化剂的Nafion膜厚度很小, 以至 于它的阻抗可忽略不计 ${ }^{[54]}$, 所以(1)式可以近似为(2)式.

$$
1 / j=1 / j_{\mathrm{k}}+1 / j_{\mathrm{d}}
$$

$$
\begin{gathered}
j_{\mathrm{d}}=0.620 n F D^{2 / 3} C_{\mathrm{o}} v^{-1 / 6} \omega^{1 / 2} \\
j_{\mathrm{k}}=n F k C_{\mathrm{o}}
\end{gathered}
$$

$j$ 是实验测量的电流密度 $\left(\mathrm{mA} / \mathrm{cm}^{2}\right), j_{\mathrm{k}}$ 和 $j_{\mathrm{d}}$ 分别是动 力学电流密度 $\left(\mathrm{mA} / \mathrm{cm}^{2}\right)$ 和扩散极限电流密度 $\left(\mathrm{mA} / \mathrm{cm}^{2}\right)$, $j_{\mathrm{f}}$ 是通过Nafion膜的扩散限制电流密度 $\left(\mathrm{mA} / \mathrm{cm}^{2}\right), n$ 是每 个 $\mathrm{O}_{2}$ 分子转移的电子数, $k$ 是ORR 的速率常数, $F$ 是法拉 第常数 $(96485 \mathrm{C} / \mathrm{mol}), \omega$ 是旋转圆盘电极的角速率, $C_{0}$ 是 $\mathrm{KOH}$ 电解液 $(0.1 \mathrm{~mol} / \mathrm{L})$ 中的 $\mathrm{O}_{2}$ 浓度 $\left(1.21 \times 10^{-6}\right.$ $\left.\mathrm{mol} / \mathrm{cm}^{3}\right)^{[55]}, D$ 是 $\mathrm{O}_{2}$ 在 $\mathrm{KOH}$ 溶液 $(0.1 \mathrm{~mol} / \mathrm{L})$ 中的扩散系 数 $\left(1.73 \times 10^{-5} \mathrm{~cm}^{2} / \mathrm{s}\right)^{[52]}, v$ 是电解液的黏滞阻力系数 $(0.01$ $\left.\mathrm{cm}^{2} / \mathrm{s}\right)$.

图9为 $\mathrm{MOF}(\mathrm{Fe})+\mathrm{SP}$ 在不同电位下催化 $\mathrm{ORR}$ 反应的 K-L图. 可以看出, $-1 / j_{\mathrm{d}}$ 对 $\omega^{-1 / 2}$ 呈良好的线性关系, 且截 距不为零, 符合 $\mathrm{K}-\mathrm{L}$ 关系式. 当电位在 -0.30 到 $-0.95 \mathrm{~V}$ 的 范围时, K-L曲线的截距均大于 0 , 表明电位在此范围内, 反应受扩散和动力学混合控制.

通常, 在碱性电解液中ORR反应有两种电子转移的 途径 ${ }^{[56]}$ :

(i)直接四电子途径

$$
\mathrm{O}_{2}+\mathrm{H}_{2} \mathrm{O}+4 \mathrm{e}^{-} \rightarrow 4 \mathrm{OH}^{-}
$$

(ii) 间接二电子途径

$\mathrm{O}_{2}+\mathrm{H}_{2} \mathrm{O}+2 \mathrm{e}^{-} \leftrightarrow \mathrm{HO}_{2}^{-}+\mathrm{OH}^{-}$或者伴随进一步的 还原反应

或者发生分解反应

$$
\begin{gathered}
\mathrm{HO}_{2}^{-}+\mathrm{H}_{2} \mathrm{O}+2 \mathrm{e}^{-} \rightarrow 3 \mathrm{OH}^{-} \\
2 \mathrm{HO}_{2}^{-} \rightarrow 2 \mathrm{OH}^{-}+\mathrm{O}_{2}
\end{gathered}
$$

从 K-L方程计算的ORR反应中每个 $\mathrm{O}_{2}$ 分子转移的电 子数如图 10 所示, 电位在 -0.50 到 $-0.30 \mathrm{~V}$ 范围内, $\mathrm{ORR}$ 反 应基本为 2 电子途径; 随着电位从 $-0.50 \mathrm{~V}$ 增加到 -0.95 $\mathrm{V}, \mathrm{ORR}$ 反应从 2 电子途径向 4 电子途径转变, 因此, 该范 围内ORR反应是 2 电子和 4 电子混合途径. 采用 Tafel方 程 $\eta=a+b \lg i\left(a=\left(2.3 R T \lg i_{0}\right) / \alpha F ; b=-2.3 R T / \alpha F\right)$ 对 1600 $\mathrm{r} / \mathrm{min}$ 下ORR极化曲线进行了处理, 发现在 -0.3 到 $-0.4 \mathrm{~V}$ 范围内符合 $\mathrm{Tafel}$ 关系, 并对动力学参数进行了计算, 得 到 $a=1.355 \mathrm{~V}, b=137 \mathrm{mV} / \mathrm{dec}, i_{0}=1.2867 \times 10^{-10} \mathrm{~A} / \mathrm{cm}^{2}$.

保持旋转圆盘电极转速为 $1600 \mathrm{r} / \mathrm{min}$, 电位为 -0.4 $\mathrm{V}$, 在 $0.1 \mathrm{~mol} / \mathrm{L} \mathrm{KOH}$ 溶液中, 采用计时电流法研究了 $\mathrm{MOF}(\mathrm{Fe})+\mathrm{SP}$ 的ORR活性保持率, 为了比较, 也测试了 商业 $\mathrm{Pt} / \mathrm{C}$ 催化剂的 ORR活性保持率, 结果如图 11所示. 可以看到, 经过 $30000 \mathrm{~s}$ 的稳定性测试后, 商业 $\mathrm{Pt} / \mathrm{C}$ 催化 剂的ORR 电流保持率为 $90 \%$, 而 $\mathrm{MOF}(\mathrm{Fe})+\mathrm{SP}$ 的ORR电 流保持率为 $81 \%$. 尽管所制 $\mathrm{MOF}(\mathrm{Fe})$ 的ORR 催化性能还 
低于商业 $\mathrm{Pt} / \mathrm{C}$, 但是通过深入系统的研究, 有望制备出高 效的基于MOFs的电化学催化剂.

\section{4. 结论}

采用水热合成法制备了的 $\mathrm{MOF}(\mathrm{Fe})$ 样品具有很好 的晶相结构、高的比表面积和很好的热稳定性且在碱性 电解质中表现出很好的OER和ORR双功能催化活性, 这
可归因于其高比表面积、丰富的微孔、众多的不饱和金 属离子催化活性位. 结果表明ORR的反应历程随电位的 改变而改变: 电位为 -0.30 到 $-0.50 \mathrm{~V}$ 范围内, $\mathrm{ORR}$ 反应为 2 电子途径; 随着电位从一 $-0.50 \mathrm{~V}$ 增加到 $-0.95 \mathrm{~V}, \mathrm{ORR}$ 反 应从 2 电子途径向 4 电子途径转变. 本文为研发用于可充 电锂-空气电池的高性能、价廉和环境友好的双功能非 贵金属催化剂开辟了新的途径. 